\title{
Artemisinin Reduces Lipid Accumulation in Hepatocytes by Inhibition of CD36 Expression
}

\author{
Jian Wang, Song Wang, Xiaonan Zhang, Linlin Hu, Ping Shi* \\ State Key Laboratory of Bioreactor Engineering, East China University of Science and Technology, Shanghai, P.R. CHINA.
}

\begin{abstract}
Background: Artemisinin, a kind of sesquiterpene lactone endoperoxide, is isolated from Artemisia annua., has been used to effectively treat different forms of malaria. Recently, some researchers showed that artemisinin decreased serum triacylglycerol in rats. However, the molecular mechanism remains unclear. Aim: In this study, we investigated the effect of artemisinin on lipid accumulation in an in vitro model of NAFLD. Methods: The cytotoxicity of $\mathrm{OA}$ and artemisinin on SMMC-7721 cells was measured by using the WST-8 based Colorimetric Assay Cell Counting kit8. To establish an in vitro cellular model of NAFLD, the human hepatocarcinoma SMMC-7721 cells were treated with OA. Lipid and TAG contents were measured by Oil Red $O$ staining and enzymatic assay. Effects of artemisinin on expression of lipogenic and lipolytic genes in SMMC-7721 cells were analyzed by RT-PCR, real time PCR and Western Blotting. Results: The in vitro model of NAFLD was constructed in SMMC-7721 cells with the addition of 1.0 $\mathrm{mM} O A$. Artemisinin reduced intracellular lipid accumulation and TAG concentration in SMMC-7721 cells induced by OA. The addition of artemisnin induced a decrease in the mRNA and protein level of CD36, while it had no effect on both mRNA and protein level of PPAR $\alpha$ and SREBP1. Conclusion: Artemisinin can reduce hepatocellular lipid accumulation and triacylglycerol content via the inhibition of CD36 expression.
\end{abstract}

Key words: Artemisinin, CD36, Hepatic lipid accumulation, NAFLD, SMMC-7721 Cells.

\section{INTRODUCTION}

With the increasing numbers of adults and children who are obese or overweight, nonalcoholic fatty liver disease (NAFLD) is a highly prevalent chronic liver disease. ${ }^{1,2}$ It encompasses a wide spectrum of liver disorders and damages characterized by hepatic steatosis without significant alcohol consumption, including simple steatosis, inflammatory non-alcoholic steatohepatitis (NASH), liver cirrhosis and hepatocellular carcinoma. ${ }^{3,4}$ So far, the validated therapy of NAFLD remains uncertain.

Traditional Chinese medicines have long been used to treat NAFLD with few adverse effects. ${ }^{5}$ Artemisinin, or qinghaosu, a sesquiterpene lactone endoperoxide, is isolated from Artemisia annua. (sweet or annual wormwood) that has been used as a herbal remedy for fever and malaria. ${ }^{6,7}$ It is exciting that $\mathrm{Tu}$ Youyou was awarded half of the 2015
Nobel Prize in Medicine because of her discovery concerning a novel therapy of artemisinin against malaria. Recently, artemisinin and its derivatives have been shown to induce growth arrest and apoptosis, ${ }^{8-10}$ as well as inhibit angiogenesis by downregulation of the vascular endothelial growth factor and its cellular receptor KDR/ flk-1. ${ }^{11,12}$ Furthermore, artemisinin inhibits rat cardiac hypertrophy, ${ }^{13}$ prevents in vitro and in vivo invasion and metastasis of human hepatocellular carcinoma cells ${ }^{14}$ and has function of anti-inflammatory and immunomodulatory on contact hypersensitivity. ${ }^{15}$ Aniefiok et al. (2010) found that artemisinin increased total serum cholesterol level, decreased serum triacylglycerol (TAG) level and reversed the ratio of Low Density Lipoprotein to High Density Lipoprotein from
Submission Date: 27-12-2016; Revision Date: 24-01-2017; Accepted Date: 14-03-2017

DOI: 10.5530/ijper.51.3.66 Correspondence:

Ping Shi,

State Key Laboratory of

Bioreactor Engineering, East

China University of Science and Technology, 130 Meilong Road, Shanghai 200237, CHINA.

Phone numbers: (086) 21-64251655

Facsimile numbers: (086) 21-64252920

E mail: ship@ecust.edu.cn.

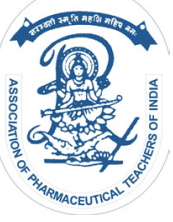

www.ijper.org 
1:2 to $2: 1$ in rats. ${ }^{16}$ However, its molecular mechanism involved in lipid metabolism is unclear.

Although the pathogenesis of NAFLD is not completely understood, hepatic lipid metabolic disorders are likely to play important roles in its initiation and development. ${ }^{17}$ Previous studies have shown that CD36, PPAR $\alpha$, and SREBP1 are important molecules in regulating fatty acid transport, lipolysis, and lipogenesis, respectively. They play important roles in hepatic and myocardial accumulation of triglyceride. ${ }^{18-22}$ Additionally, in vitro models of NAFLD have been constructed and used to study the hepatic lipid metabolic disorders in hepatic cells and screen drug candidates for suitability for the treatment of NAFLD. ${ }^{23,24}$ These models include hepatocyte cell lines and primary hepatocytes treated in culture with monounsaturated and saturated fatty acids, which simulate the key characteristics of NAFLD in human liver. ${ }^{25,26}$ Therefore, in order to understand the probable molecular mechanism of artemisinin involved in hepatic lipid metabolism, it is essential to investigate the effect of artemisinin on CD36, PPAR $\alpha$, and SREBP1 in the in vitro model.

In the present study, we explored the alleviation of lipid accumulation effect of artemisinin on an in vitro model of NAFLD. Our results demonstrated that artemisinin attenuated lipid accumulation via the downregulation of CD36. It is expected that artemisinin may be a therapeutic candidate of the treatment of NAFLD in the near future.

\section{MATERIALS AND METHODS}

\section{Antibodies and reagents}

CD36, PPAR $\alpha$ and SREBP1 rabbit polyclonal antibody were purchased from Santa Cruz Biotechnology Inc. (Texas, USA). $\beta$-actin rabbit monoclonal antibody was purchased from Cell Signaling Technology Inc. (MA, USA). The secondary antibody HRP-labeled Goat Anti-Rabbit IgG $(\mathrm{H}+\mathrm{L})$ was purchased from Novo protein Scientific Inc. (Shanghai, China). Reagents used in SDS-polyacrylamide gel electrophoresis were purchased from Shenghong Company (Shanghai, China). Other reagents used in our study were purchased from Solarbio life science (Beijing, China). Artemisinin (purity $\geq$ 98\%) was purchased from Alexis Biochemistry (New York, USA). Its chemical structure was shown in Figure 1A.

\section{Cell culture and Treatments}

The human liver cancer SMMC-7721 cell line was supplied by the Institute of Cell Biology (Shanghai, China). They were cultured at $37{ }^{\circ} \mathrm{C}$ under a humidified $5 \% \mathrm{CO}_{2}$ atmosphere in RPMI-1640 medium (GIBCO/
Invitrogen, Camarillo, CA, USA) supplemented with 10\% fetal bovine serume (Biological Industry, Kibbutz Beit Haemek, Israel) and 1\% penicillin-streptomycin $(10,000 \mathrm{U} / \mathrm{ml}$ penicillin and $10 \mathrm{mg} / \mathrm{ml}$ streptomycin, Solarbio life science, Beijing, China). Other reagents used in our study were purchased from Solarbio life science Co., Ltd (Beijing, China) and Aladdin Industrial Corporation (Los Angeles, USA). Artemisinin was dissolved in dimethylsulfoxide (DMSO) to a concentration of $200 \mu \mathrm{M}$ (final concentration of DMSO was less than $0.1 \%$ by volume) and was added at the indicated concentrations in SMMC-7721 cells.

\section{Cell viability assay}

Cell viability was evaluated by Cell Counting Kit-8 (Dojindo, Tokyo, Japan) according to the manufacturer's instruction. Cells were plated in 96-well micro-well plate in $0.1 \mathrm{ml}$ volume of RPMI-1640 medium with $10 \%$ FBS, at a density of $0.1 \times 10^{5}$ cells/well. Absorbance was measured at $450 \mathrm{~nm}$ with an iMark Microplate reader (Bio-Rad, California, USA).

\section{Oil Red 0 staining}

The SMMC-7721 cells at $0.5 \times 10^{5}$ cells/well were seeded in 48-well plates and pre-incubated with RMPI 1640 containing $10 \%$ of FBS for $12 \mathrm{~h}$. The cells were then exposed to different concentration of artemisinin for $12 \mathrm{~h}$ and then treated with $0.5 \mathrm{mM}$ or $1.0 \mathrm{mM}$ oleic acid (OA) for $24 \mathrm{~h}$ or $48 \mathrm{~h}$, fixed with $4 \%$ paraformaldehyde and stained with a freshly prepared working solution of Oil Red O (three parts of 1\% stock in isopropanol and two parts double distilled $\mathrm{H}_{2} \mathrm{O}$ ) for $30 \mathrm{~min}$ at room temperature. The stained cells were observed under a fluorescence microscope (Olympus BX51, Tokyo, Japan). To quantify the Oil Red O content, isopropanol was added to each sample, which was shaken at room temperature for $5 \mathrm{~min}$, and the optical density of each $100 \mu$ lisopropanol extracted sample was read with a spectrophotometer (Bio Tek Synergy2, Vermont, American) at $510 \mathrm{~nm}$.

\section{Measurement of cellular triglyceride concentration in SMMC-7721 cells}

The concentration of triglyceride (TAG) in cells was measured with enzymatic assays from Nanjing Jiangcheng Bioengineering Institute (Nanjing, China), according to the manufacturer's instructions. Absorbance was measured with a microplate spectrophotometric system at 546 $\mathrm{nm}$. The result of TAG was expressed as mmol TAG per $g$ protein ( $\mathrm{mmol} / \mathrm{g}$ protein). 


\section{Reverse Transcription-Polymerase Chain Reaction and real time PCR}

The expression of CD36, PPAR $\alpha$ and SREBP1 mRNA in the cells was determined by Reverse TranscriptionPolymerase Chain Reaction (RT-PCR) and real- time PCR. The cells $\left(5 \times 10^{5}\right.$ cells/well $)$ in 6 -well plates were pre-treated with artemisinin at indicated concentration for $12 \mathrm{~h}$ and then treated with $1.0 \mathrm{mM}$ OA for $24 \mathrm{~h}$. Total RNA was prepared from cells using cold Trizol (Takara, Japan) according to the manufacturer's protocol. The cDNA was synthesized by reverse transcription with PrimeScrtipt RT regent kits (Takara, Japan) according to the manufacturer's protocol and then subjected to PCR and real-time PCR detection with Emerald Amp PCR Master Mix and SYBR Premix Ex Taq (Tli RNAaseH Plus) kit (Takara, Japan). The primer sequences were as follows: 5'-GAGAACTGTTATGGGGCTAT-3' (sense), 5'-T'TCAACTGGAGA GGCAAAGG-3' (antisense) for CD36, 5'-GCGATCTA GAGAGCCC GT'TATC-3' (sense), 5'-GCCAAAGCT'T CCAGAACTATCC-3' (antisense) for PPAR $\alpha, 5^{\prime}-\mathrm{CT}$ GGTCGTAGATGCGGAGAA-3' (sense), 5'-CAT'TGATGGAGGAGCGGTAG-3' (anti-sense) for SREBP1 and 5'-CGGCTACCACATCCAAGGAAG-3' (sense), 5'AGCTGGAATTACCG CGGCT-3' (antisense) for 18s RNA.

\section{Western Blotting}

The cell pellets were collected by centrifugation and washed two times with cold PBS, then dissolved in lysis buffer and lysis for $30 \mathrm{~min}$. Insoluble materials were removed by centrifugation, the supernatant was saved and protein content was determined by the Bradford method (Bradford, 1976). Protein $(50-80 \mu \mathrm{g})$ were separated on $8 \%$ SDS-PAGE (laemmli, 1970) and transferred to Amersham Hybond-P polyvinyliden fluoride(PVDF) membrans (GE healthcare, Buckinghamshire, UK) and probed with specific primary antibodies and then with secondary antibody. Proteins were detected using a chemiluminescense-based kit (Tian Gen Biotech Co., Ltd, China). Signal density was detected using the MF-Chemi BIS Family including gel capture software (DNR Bio-Image system, Ltd., Jerusalem, Israel) and quantitatively analyzed by densitometry using the Image J software.

\section{Statistical Analysis}

Values were expressed as means \pm standard deviations. Statistical analysis was performed using the Student's $t$-test. Values of $p<0.05$ were considered to be statistically signinficant.

\section{RESULTS}

\section{Cytotoxic effect of artemisinin and OA on SMMC- 7721 cells}

Using the WST-8 based Colorimetric Assay Cell Counting kit 8 , the cytotoxicity of $\mathrm{OA}$ and artemisinin on SMMC7721 cells was measured. After treatment for 24, 48 and $72 \mathrm{~h}, 0.5 \mathrm{mM}$ and $1.0 \mathrm{mM}$ OA had no obvious effect on the viability of SMMC-7721 cells, however $1.5 \mathrm{mM}$ and $2.0 \mathrm{mM}$ OA caused $10 \%$ and $81 \%$ cell death compared with control separately after treating for $24 \mathrm{~h}$ (Fig.1 B). At $24 \mathrm{~h}$ and $48 \mathrm{~h}, 50 \mu \mathrm{M}$ and $100 \mu \mathrm{M}$ artemisinin had no effect on cell viability of SMMC-7721 cells. However, when treated cells with $100 \mu \mathrm{M}$ artemisinin for $72 \mathrm{~h}$, $17 \%$ cells were dead and treatment of $200 \mu \mathrm{M}$ artemisinin caused more than 50\% cells death (Figure $1 \mathrm{C}$ ).

\section{Construction an in vitro model of NAFLD by OA}

To establish an in vitro cellular model of NAFLD, SMMC-7721 cells were treated with different concentrations of OA. As shown in Figure 2A, $0.5 \mathrm{mM}$ and 1.0 $\mathrm{mM} \mathrm{OA}$ increased numbers of lipid droplets compared with control cells and $1.0 \mathrm{mM}$ OA caused more lipid droplets than $0.5 \mathrm{mM}$ OA. Furthermore, as shown in Figure 2B, lipid content was significantly elevated in a concentration-dependent manner. After treated for $24 \mathrm{~h}$ and $48 \mathrm{~h}$, the lipid content in cells treated with $1.0 \mathrm{mM}$ OA was 1.7 and 1.4 times than those treated with $0.5 \mathrm{mM}$ OA. According to these data, we chose $1.0 \mathrm{mM} \mathrm{OA}$ to construct the in vitro model of NAFLD.

\section{Artemisinin reduced intracellular lipid accumulation and TAG concentration in SMMC-7721 cells induced by $O A$}

Next, $50 \mu \mathrm{M}$ and $100 \mu \mathrm{M}$ artemisinin was chosen to treat model cells of NAFLD. As shown in Figure 3A, there was significant difference between cells treated with or without $100 \mu \mathrm{M}$ artemisinin. The numbers and sizes of the lipid droplets were significantly reduced after the treatment of $100 \mu \mathrm{M}$ artemisinin with the observation of fluorescence microscope and $50 \mu \mathrm{M}$ artemisinin had no effect. Furthermore, lipid content was significantly elevated after treated with $1.0 \mathrm{mM}$ OA for $24 \mathrm{~h}$, compared with the control cells $(p<0.01)$, while $100 \mu \mathrm{M}$ artemisinin decreased lipid content induced by $1.0 \mathrm{mM}$ OA $(p<0.05)$ in SMMC-7721 cells (Figure 3B). Compared to $0.272 \mathrm{mmol} / \mathrm{g}$ protein in the control group, the intracellular TAG content increased significantly in the OA treated cells and reached $0.596 \mathrm{mmol} / \mathrm{g}$ protein $(p<0.01$ versus the control), and decreased significantly after treated with $100 \mu \mathrm{M}$ artemisinin and it was 0.378 $\mathrm{mmol} / \mathrm{g}$ protein $(p<0.01$ versus the OA treated cells) (Figure 3C). The results showed that artemisinin reduced 


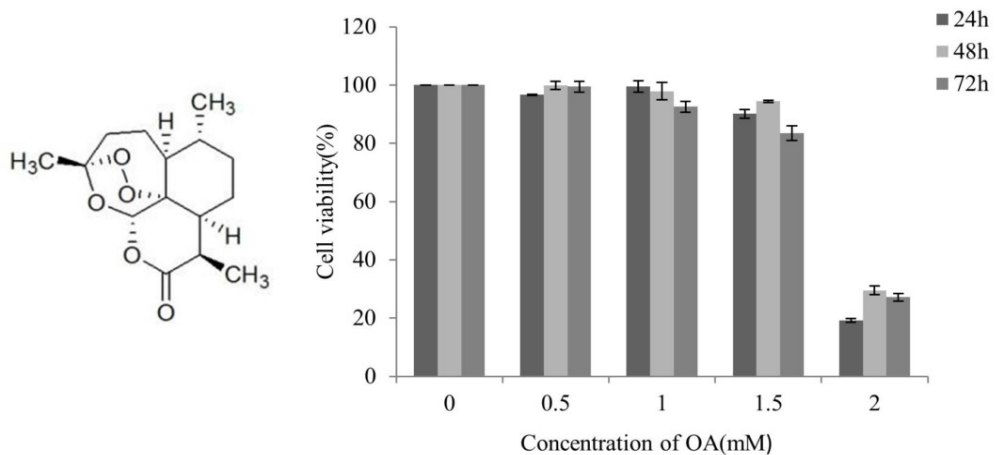

(A)

(B)

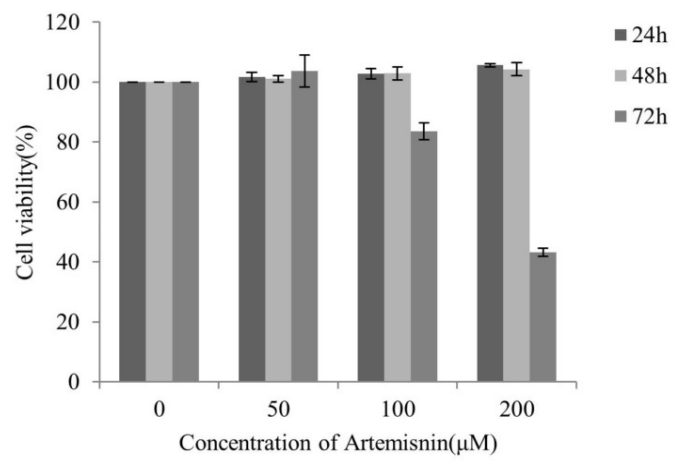

(C)

Figure 1: Chemical strcture of artemisinin (A) and the effects of OA or artemisinin on SMMC-7721 cells viability (B and C). Various concentrations of OA $(0-2.0 \mathrm{mM})$ or artemisinin $(0-200 \mu \mathrm{M})$ were used to treat human SMMC-7721 hepatoma cells for 24, 48 and $72 \mathrm{~h}$. Cell viability was measured by CCK-8 assay. The experiments were repeated three times and the data were presented as means $\pm S D$ for triplicate experiments.

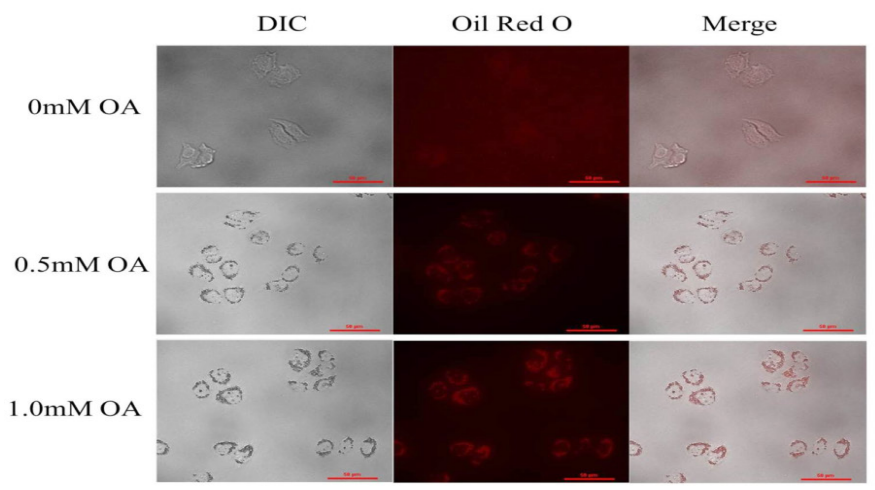

(A)

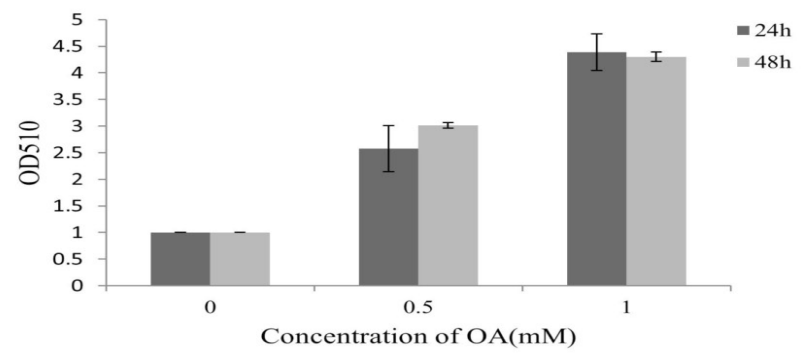

(B)

Figure 2: Construction of an in vitro model of NAFLD. The SMMC-7721 cells were treated with OA (0-1.0 mM) for $24 \mathrm{~h}$, then were stained by Oil Red $O$ (A). Lipid concentration in cells treated with OA was measured by Oil Red $O$ staining (B). Data are presented as means \pm SD for triplicate experiments.
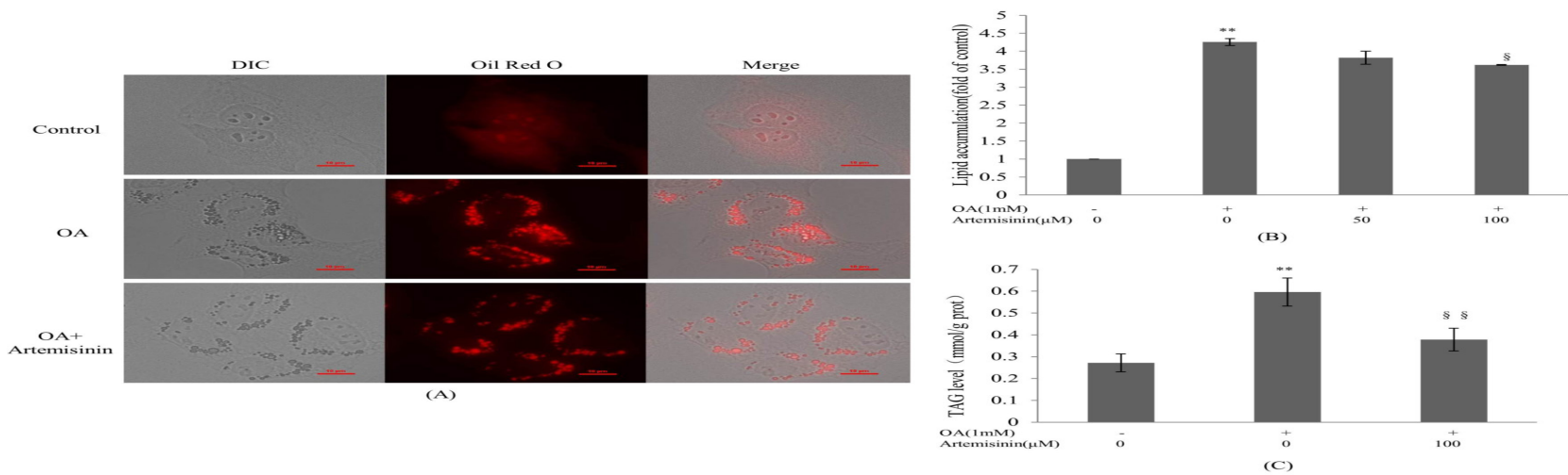

Figure 3: Artemisinin inhibits OA induced intracellular lipid accumulation. The cells were pre-treated with artemisinin (100 $\mu \mathrm{M})$ for $12 \mathrm{~h}$, and then were treated with $O A(1.0 \mathrm{mM})$ for $24 \mathrm{~h}$. In the indicate time, cells were stained by Oil Red $\mathrm{O}(\mathrm{A})$. In the indicate time, the lipid content in SMMC-7721 cells was measured by Oil Red O colorimetric assay (B) and intracellular TAG content was measured by TAG kit (C). Results are expressed as means $\pm S$.D for triplicate experiments. " $p<0.01$ compared to the control group; ${ }^{\S} p<0.05,{ }^{\S} p<0.01$ compared to OA group. 

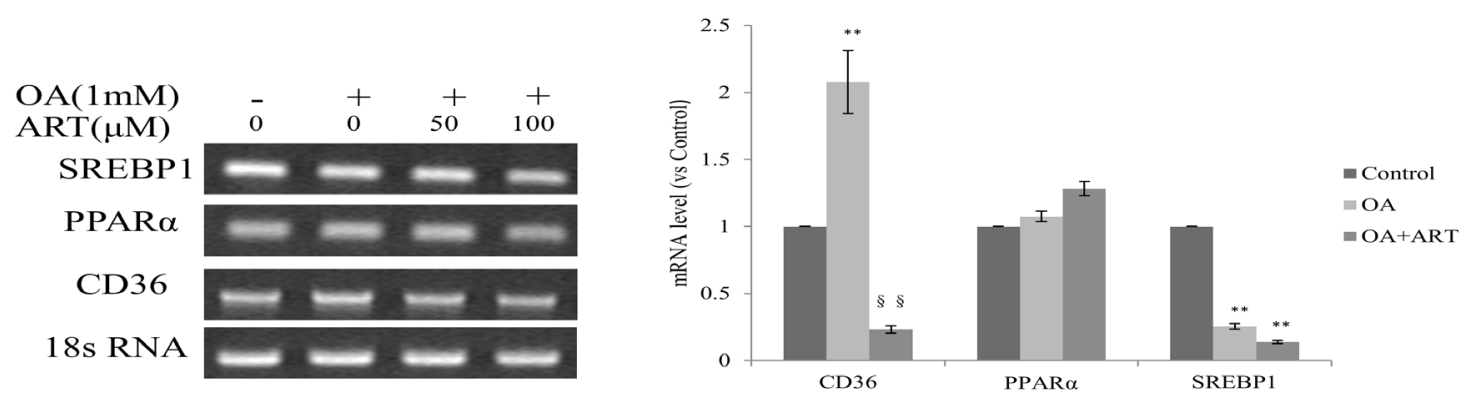

Figure 4: Effects of artemisinin on mRNA expression of lipogenic and lipolytic genes in SMMC-7721 cells by RT-PCR (A) and real-time PCR (B). The cells were pre-treated with artemisinin $(100 \mu \mathrm{M})$ for $12 \mathrm{~h}$, then were treated with OA (1.0 mM) for $24 \mathrm{~h}$. The amount of mRNA in the treated cells was normalized to that of the untreated control (Control). Data were expressed as mean \pm SD relative to the corresponding basal mRNA level from at least three independent experiments. ${ }^{* *} p<0.01$ compared to the control group; ${ }^{\$}{ }^{p}<0.01$ compared to the OA group.
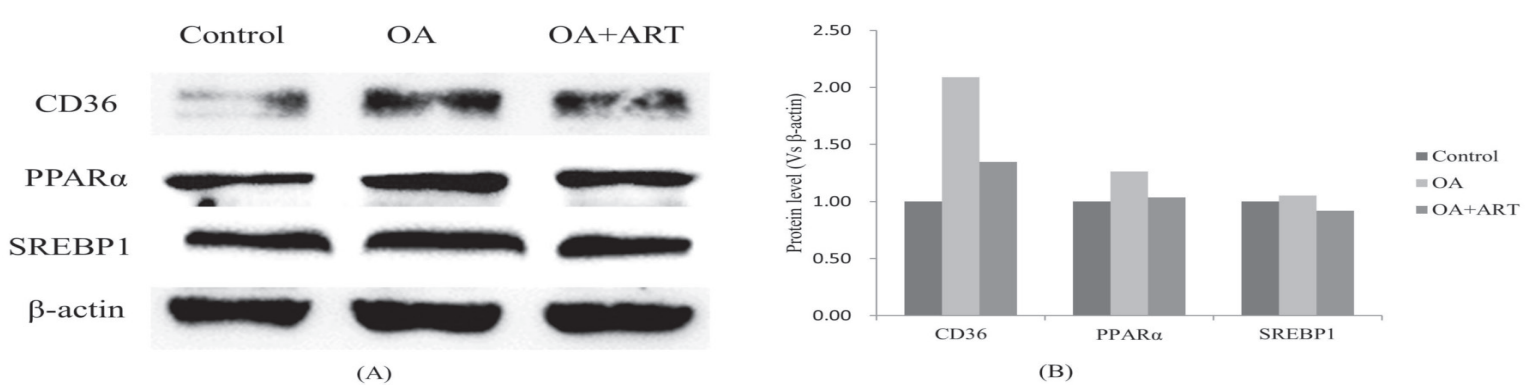

Figure 5: Effects of ART on protein expression of lipogenic and lipolytic genes in SMMC-7721 cells by western blot. The cells were pre-treated with artemisinin $(100 \mu \mathrm{M})$ for $12 \mathrm{~h}$, then were treated with OA (1.0 mM) fo $24 \mathrm{~h}$. Panels A shows the immunoreactive bands of CD36, PPARa, SREBP1 and $\beta$-actin obtained from control, OA or OA with artemisinin treated SMMC-7721 cells, respectively. Panel B shows the average intensity level of CD36, PPARa and SREBP1 after normalization with the $\beta$-actin intensity.

intracellular lipid accumulation and TAG concentration in the cellular model of NAFLD.

\section{Effects of artemisinin on expression of lipogenic and lipolytic genes in SMMC-7721 cells}

The mRNA levels of CD36, PPAR $\alpha$, SREBP1 in different treated cells were detected by RT-PCR and real-time PCR, respectively. The results were shown in Figure 4, the mRNA expression of CD36 was significantly up-regulated about 2-fold in the OA group compared with that in the control group $(p<0.01)$. However, the up-regulated effect of $\mathrm{OA}$ was decreased to 0.23 fold of control group by $100 \mu \mathrm{M}$ artemisinin $(p<0.01)$. The mRNA of SREBP1 was both decreased in OA and OA with artemisinin groups compared with control group $(p<0.01)$, however artemisinin had no effect on mRNA expression of SREBP1compared to OA group. In contrast, the mRNA expression of PPAR $\alpha$ had no change in both OA and OA with artemisinin groups and artemisinin had no effect on it.

The proteins of CD36, PPAR $\alpha$, SREBP1 were detected by western blot, respectively. The results were presented in Figure 5. The level of CD36 in OA group was elevated and decreased by artemisinin, similar as the result of mRNA expression. PPAR $\alpha$ and SREBP1 protein levels were different from their mRNA expressions, which were up-regulated by $\mathrm{OA}$ while artemisinin did not change their high levels.

\section{DISCUSSION}

According to our previous studies, OA was chosen to treat SMMC-7721 cells to establish an in vitro model of NAFLD. ${ }^{27,28}$ The present results showed that intracellular lipid droplets increased significantly in the OAtreated cells, indicating that the in vitro NAFLD model had been successfully established. In this cellular model, we observed that intracellular lipid accumulation and TAG concentration were significantly reduced by $100 \mu \mathrm{M}$ artemisinin. Additionally, artemisinin was found to down-regulate both mRNA and protein expressions of CD36 and have no effect on those of PPAR $\alpha$ and SREBP1. As very important molecules in regulating lipid metabolism, PPAR $\alpha$ is a nuclear receptor expressed primarily 


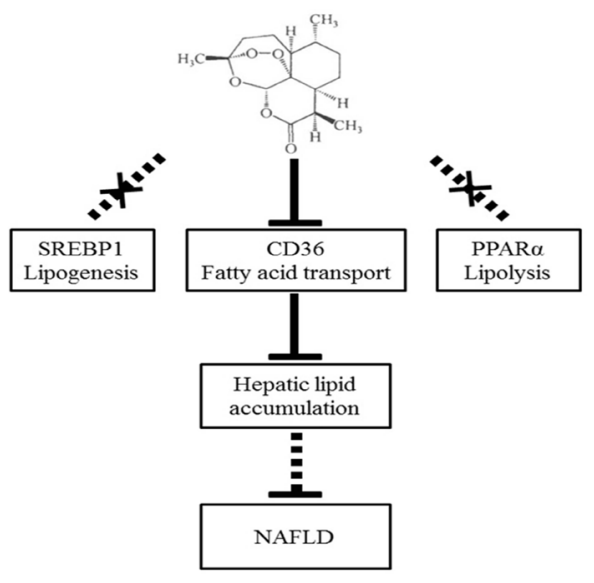

Figure 6: Potential molecular mechanism of artemisinin on the reduction of hepatic lipid accumulation.

in the liver and regulates the transcription of genes involved in hepatic fatty acid uptake and oxidation. ${ }^{29-30}$ While SREBP1 is the most important transcription factor regulation gene involved in de novo lipogenesis. ${ }^{31}$ From our results, it suggests that artemisinin had no impact on hepatocellular lipid synthesis and fatty acid oxidation.

CD36/FAT resides in the plasma membrane of hepatocytes and is known to translocate to the outer mitochondrial membrane to facilitate uptake and transport of fatty acids across the mitochondrial membrane. ${ }^{32}$ Previously, Koonen et al. found that high-fat diet increased expression of hepatic CD36 protein and hepatic triglyceride storage. ${ }^{18}$ In CD36 knockout mice, uptake and utilization of long chain fatty acids in muscle and adipose tissues was reduced. ${ }^{33}$ Krammer et al. once reported that overexpression of CD36 in Huh 7 and HepG2 cells increased uptake of OA. ${ }^{34}$ Podszun et al. indicated that orally administered atorvastatin and RRR$\alpha$-tocopherol $(\alpha \mathrm{T})$ individually, but not synergistically, prevent diet-induced lipid accumulation in the liver of guinea pigs by down-regulation of hepatic CD36 protein. ${ }^{35}$ In our work, it showed that $\mathrm{OA}$ induced up-regulation of CD36 and increase of TAG, while artemisinin reduced the expression of CD36 and lipid accumulation. It suggests that artemisinin reduced hepatic lipid accumulation via down-regulation of CD36 protein. For another, Puthanveetila et al. indicated that excess lipid induce cardiac triglyceride accumulation through activation of a FoxO1-iNOS-CD36 pathway. ${ }^{36}$ Wang et al. demonstrated that rapamycin inhibits hepatic CD36 translational efficiency through the mTOR pathway, resulting in reduction of CD36 protein expression and alleviation of hepatic steatosis. ${ }^{37}$ Future studies are required to explore the molecular mechanism of artermisinin involved in lipid metabolism via inhibition of CD36 protein.

\section{CONCLUSION}

In conclusion, we demonstrated that artemisinin attenuated lipid accumulation via the downregulation of CD36 in the cellular model of NAFLD (Figure 6). The results obtained here suggest that artemisinin may be a therapeutic candidate of the treatment of NAFLD in the near future.

\section{ACKNOWLEDGEMENT}

This work was sponsored by grants from National Natural Science Foundation of China (31671309), Shanghai Scientific and Technological Innovation Project (14520720700), State Education Ministry and Fundamental Research Funds for the Central Universities (222201313010).

\section{CONFLICT OF INTEREST}

The authors declare no conflict of interest.

\section{ABBREVIATION USED}

NAFLD: Nonalcoholic fatty liver disease; TAG: Triacylglycerol; OA: Oleic acid; RT-PCR: Reverse transcription-polymerase chain reaction; CD36: Cluster of differentiation 36; PPAR $\square$ : Peroxisome proliferator-activated receptor; SREBP1: Sterol regulatory element-binding transcription factor 1; FBS: Fetal bovine serume; DMSO: Dimethylsulfoxide.

\section{REFERENCES}

1. Hesham AH. Nonalcoholic fatty liver disease in children living in the obeseogenic society. World J Pediatr. 2009;5(4):245-54. https://doi. org/10.1007/s12519-009-0048-8; PMid:19911138.

2. Trauner M, Arrese M, Wagner M. Fatty liver and lipotoxicity. BBA-Mol. Cell Biol. L. 2010;1801(3):299-310. https://doi.org/10.1016/j.bbalip.2009.10.007; PMid:19857603

3. Contos MJ, Choudhury J, Mills AS, Sanyal AJ. The histologic spectrum of nonalcoholic fatty liver disease. Clin. Liver Dis. 2004;8:481-500. https://doi. org/10.1016/j.cld.2004.04.013; PMid:15331059.

4. Byrne CD, Targher G. NAFLD: A multisystem disease. J Hepatol. 2015;62(1):47-64. https://doi.org/10.1016/j.jhep.2014.12.012; PMid:25920090.

5. Chen J, Zhao H, Yang Y, Liu B, Ni J, Wang W. Lipid-lowering and antioxidant activities of Jiang-Zhi-Ning in Traditional Chinese Medicine. J. Ethnopharmacol. 2011;134(3):919-30. https://doi.org/10.1016/j. jep.2011.01.048;p PMid:21316437

6. Miller LH, Su X. Artemisinin: Discovery from the Chinese Herbal Garden. Cell. 2011;s146(6)s:855-8.

7. Duffy PE, Mutabingwa TK. Drug combinations for malaria: time to ACT? The Lancet. 2004;363(9402):3-4. https://doi.org/10.1016/S0140-6736(03)15230-0.

8. Beekman AC, Woerdenbag HJ, Van-Uden W, Pras N, Konings AW, Wikstrom HV. Stability of artemisinin in aqueous environments: impact on its cytotoxic 
action to Ehrlich ascites tumour cells. J Pharm Pharmacol. 1997;49(12):12548. https://doi.org/10.1111/j.2042-7158.1997.tb06080.x; PMid:9466353.

9. Sadava D, Phillips T, Li C, Kane SE. Transferrin overcomes drug resistance to artemisinin in human small-cell lung carcinoma cells. Cancer Lett. 2002;179(2):151-6. https://doi.org/10.1016/S0304-3835(02)00005-8.

10. Yamachika E, Habte T, Oda D. Artemisinin: an alternative treatment for oral squamous cell carcinoma. Anticancer Res. 2004;24(4):2153-60. PMid: 15330155.

11. Chen $\mathrm{H}$, Zhou $\mathrm{H}$, Fang $\mathrm{X}$. Inhibition of human cancer cell line growth and human umbilical vein endothelial cell angiogenesis by artemisinin derivatives in vitro. Pharmacol Res. 2003;48(3):231-6. https://doi.org/10.1016/S10436618(03)00107-5.

12. Chen H, Zhou H, Wu G, Lou X. Inhibitory effects of artesunate on angiogenesis and on expressions of vascular endothelial growth factor and VEGF receptor KDR/flk-1. Pharmacology. 2004;71(1):1-9. https://doi. org/10.1159/000076256; PMid:15051917.

13. Xiong Z, Sun G, Zhu C, Cheng B, Zhang C, Ma Y, et al. Artemisinin, an anti-malarial agent, inhibits rat cardiac hypertrophy via inhibition of NF-KB signaling. Eur J Pharmacol. 2010;649(1):277-84. https://doi.org/10.1016/j. ejphar.2010.09.018; PMid:20863781.

14. Tan W, Shen F, Luo X, Su C, Qiu Z, Zeng H, et al. Artemisinin inhibits in vitro and in vivo invasion and metastasis of human hepatocellular carcinoma cells. Phytomedicine 2011;18(2):158-62.

15. Li T, Chen H, Wei N, Mei X, Zhang S, Liu D, et al. Anti-inflammatory and immunomodulatory mechanisms of artemisinin on contact hypersensitivity. Int. Immunopharmacol. 2012;12(1):144-150. https://doi.org/10.1016/j. intimp.2011.11.004; PMid:22122827.

16. Aniefiok SU, Olorunfemi AE, Etim I, Uwemedimo U. Effect of artemisinin alone and artemisinin with folic acid on the lipid profile of rat. Int J Biol Chem Sci. 2010;4(6):2421-6.

17. Torres DM, Williams CD, Harrison SA. Features, diagnosis, and treatment of nonalcoholic fatty liver disease. Clin Gastroenterol H. 2012;10(8):837-58. https://doi.org/10.1016/j.cgh.2012.03.011; PMid:22446927.

18. Koonen DP, Jacobs RL, Febbraio M, Young ME, Soltys CL, Ong H, et al. Increased hepatic CD36 expression contributes to dyslipidemia associated with diet-induced obesity. Diabetes 2007;56(12):2863-71. https://doi. org/10.2337/db07-0907; PMid: 17728375.

19. Desvergne B, Wahli W. Peroxisome proliferators-activated receptors: nuclear control of metabolism. Endocr. Rev. 1999;20(5):649-88. https:// doi.org/10.1210/edrv.20.5.0380; https://doi.org/10.1210/er.20.5.649; PMid:10529898.

20. Pai J, Guryev O, Brown MS, Goldstein JL. Differential stimulation of cholesterol and unsaturated fatty acid biosynthesis in cells expressing individual nuclear sterol regulatory element-binding proteins. J. Biol. Chem. 1998;273(40):26138-48. https://doi.org/10.1074/jbc.273.40.26138; PMid:9748295.

21. Abumrad NA, Goldberg IJ. CD36 actions in the heart: Lipids, calcium, inflammation, repair and more? BBA- Mol. Cell Biol. L. 2016;1861(10):1442-9. https://doi.org/10.1016/j.bbalip.2016.03.015; PMid:27004753.

22. Kim TT, Dyck JR-B. The role of CD36 in the regulation of myocardial lipid metabolism. BBA- Mol. Cell Biol. L. 2016;1861(10):1450-60. https://doi. org/10.1016/j.bbalip.2016.03.018l; PMid:26995462.

23. Wang G, Fu Y, Xu W, Feng Y, Fang S, Zhou X. Resveratrol inhibits the expression of SREBP1 in cell model of steatosis via Sirt1-FOXO1 signaling pathway. Biochem. Biophys. Res. Commun. 2009;380(3):644-9. https://doi. org/10.1016/j.bbrc.2009.01.163; PMid:19285015.

24. Nanthirudjanar T, Furumoto H, Hirata T, Sugawara T. Oxidized eicosapentaenoic acids more potently reduce LXRa-induced cellular triacylglycerol via suppression of SREBP-1c, PGC-1 $\beta$ and GPA than its intact form. Lipids Health Dis. 2013;12(1):73. https://doi.org/10.1186/1476511X-12-73; PMid:23680128 PMCid:PMC3680052.

25. Malhi H, Bronk SF, Werneburg NW, Gores GJ. Free fatty acids induce JNKdependent hepatocyte lipoapoptosis. J Biol Chem. 2006;281(17):12093-101. https://doi.org/10.1074/jbc.M510660200; PMid:16505490.

26. Araya J, Rodrigo R, Videla LA, Thielemann L, Orellana M, Pettinelli P, et al. Increase in long-chain polyunsaturated fatty acid $n-6 / n-3$ ratio in relation to hepatic steatosis in patients with non-alcoholic fatty liver disease. Clin Sci. 2004;106(6):635-43. https://doi.org/10.1042/CS20030326; PMid:14720121.

27. Wang S, Kuang X, Fang Z, Huang Z, Shi P. Effect of Oleic Acid on the Levels of Eight Metal lons in Human Hepatoma SMMC-7721 Cells. Biol Trace Elem Res. 2014;159(1-3):445-50. https://doi.org/10.1007/s12011-014-0018-4; PMid:24867776.

28. Wang S, Wang J, Zhang X, Hu L, Fang Z, Huang Z, et al. Trivalent chromium alleviates oleic acid induced steatosis in SMMC-7721 cells by decreasing fatty acid uptake and triglyceride synthesis. Biometals 2016;29(5):881-92. https://doi.org/10.1007/s10534-016-9960-2; PMid:27497686.

29. Lefebvre P, Chinetti G, Fruchart JC, Staels B. Sorting out the roles of PPAR alpha in energy metabolism and vascular homeostasis. J Clin Invest. 2006;116(3):571-80. https://doi.org/10.1172/JCI27989; PMid:16511589 PMCid:PMC1386122.

30. Xu KZ, Zhu C, Kim MS, Yamahara J, Li Y. Pomegranate flower ameliorates fatty liver in an animal model of type2 diabetes and obesity. J. Ethnopharmacol. 2009;123(2):280-7. https://doi.org/10.1016/j.jep.2009.03.035; PMid:19429373.

31. Shimano H, Yahagi N, Amemiya-Kudo M, Hasty AH, Osuga J, Tamura Y, et al. Sterol regulatory element-binding protein-1 as a key transcription factor for nutritional induction of lipogenic enzyme genes. J. Biol. Chem. 1999; 274(50):35832-9. https://doi.org/10.1074/jbc.274.50.35832; PMid:10585467.

32. Smith BK, Jain SS, Rimbaud S, Dam A, Quadrilatero J, Ventura-Clapier R, et al. FAT/CD36 is located on the outer mitochondrial membrane, upstream of long-chain acyl-CoA synthetase, and regulates palmitate oxidation. Biochem. J. 2011;437(1):125-34. https://doi.org/10.1042/BJ20101861; PMid:21463259.

33. Coburn CT, Knapp FF Jr, Febbraio M, Beets AL, Silverstein RL, Abumrad NA. Defective uptake and utilization of long chain fatty acids in muscle and adipose tissues of CD36 knockout mice. J Biol Chem. 2000;275(42):32523-9. https://doi.org/10.1074/jbc.M003826200; PMid:10913136.

34. Krammer J, Digel M, Ehehalt F, Stremmel W, Fullekrug J, Ehehalt R. Overexpression of CD36 and acyl-CoA synthetases FATP2, FATP4 and ACSL1 increases fatty acid uptake in human hepatoma cells. Int. J. Med. Sci. 2011;8(7):599-614. https://doi.org/10.7150/ijms.8.599; PMid:22022213 PMCid:PMC3198256.

35. Podszun MC, Grebenstein N, Spruss A, Schlueter T, Kremoser C, Bergheim I, et al. Dietary a-tocopherol and atorvastatin reduce high-fat-induced lipid accumulation and down-regulate $\mathrm{CD} 36$ protein in the liver of guinea pigs. J. Nutr. Biochem. 2014;25(5):573-579. https://doi.org/10.1016/j. jnutbio.2014.01.008; PMid:24725433.

36. Puthanveetil P, Wang Y, Zhang D, Wang F, Kim MS, Innis S, et al. Cardiac triglyceride accumulation following acute lipid excess occurs through activation of a FoxO1-iNOS-CD36 pathway. Free Radical Bio. Med. 2011;51(2):352-63. https://doi.org/10.1016/j.freeradbiomed.2011.04.009; PMid:21545834.

37. Wang C, Yan Y, Hu L, Zhao L, Yang P, Moorhead JF, et al. Rapamycinmediated CD36 translational suppression contributes to alleviation of hepatic steatosis. Biochem. Bioph. Res. Co. 2014;447(1):57-63. https://doi. org/10.1016/j.bbrc.2014.03.103; PMid:24685479. 
PICTORIAL ABSTRACT

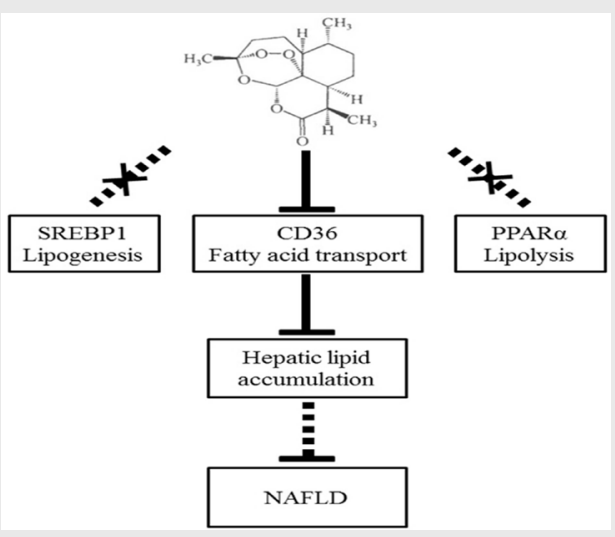

\section{SUMMARY}

- Artemisinin attenuated lipid accumulation via the downregulation of CD36 in the cellular model of NAFLD.

- Our results suggest that artemisinin may be a therapeutic candidate of the treatment of NAFLD in the near future.

\section{About Authors}

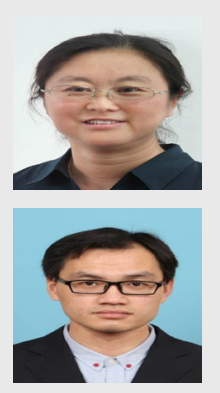

Prof. Ping Shi: Working as a teacher at State Key Laboratory of Bioreactor Engineering in East China University of Science and Technology. Her research area includes pharmacological studies on various bioactive compounds. She has over 70 scientific research papers published in international journals.

Mr. Jian Wang: Presently in a Ph.D student at State Key Laboratory of Bioreactor Engineering in East China University of Science and Technology. His research areas include pharmacological screening and active principles of traditional Chinese medicinal plants, biotechnological tools and techniques.

Cite this article: Wang J, Wang S, Zhang X, Hu L, Shi P. Artemisinin Reduces Lipid Accumulation in Hepatocytes by Inhibition of CD36 Expression. Indian J of Pharmaceutical Education and Research. 2017;51(3):393-400. 